Cezar GHEORGHE

The Centre of Excellence in Image Studies - CESI, University of Bucharest

Bucharest, Romania

gheorghecezar@yahoo.com

\title{
CROSSING BORDERS IN FILM THEORY AND ADAPTATION STUDIES
}

Recommended Citation: Gheorghe, Cezar. "Crossing Borders in Film Theory and Adaptation Studies". Metacritic Journal for Comparative Studies and Theory 7.2 (2021). Doi: https://doi.org/10.24193/mjcst.2021.12.09

\begin{abstract}
The history of film theory is full of what we might call migrating concepts. From the Russian Formalists which, in their Poetica Kino (Poetics of cinema) adapt concepts initially created as part of literary theory (fabula vs. syuzhet, film as language, cine-stylistics) to David Bordwell and Kristin Thompson and their formalist inspired approach to film studies, from André Bazin and his theory of realism, inspired by phenomenological concepts, the history of film theory can be thought of as a genealogy of crossing borders. The circulation of concepts from literary theory to film theory is also quite astonishing in the theory of adaptation. In the study of the adaptation of literary works for cinema, the travel of concepts (the crossing of borders) can be observed and analysed especially in narrative theory and adaption theory.
\end{abstract}

Keywords: Adaptation Studies, Film Adaptations, travelling concepts, theory and borders, migrating theory

\section{Introduction: "The Toolbox"}

The idea of describing theory as a "box of tools" (Foucault, Deleuze 208) is what the conversation between Michel Foucault and Gilles Deleuze on "Intellectual and Power" is most famous for. Like tools, we use and reuse theories, concepts and ideas. In fact, we might say that the strength of a theory lies in its ability to travel through time and space and through several disciplines. "As soon as a 
theory is enmeshed in a particular point, we realize that it will never possess the slightest practical importance unless it can erupt in a totally different area" (Foucault, Deleuze 208). The erruption of theories in areas different from their "point of origin" (Said 226), the becoming of theory is what we are concerned with here. To use Deleuze's terminology, theory is not sedentary, but nomadic, a smooth (lisse) space, not a striated (strié) space, it is always open to lines of flight, it opens up towards a body without organs which dismantles the conceptual organism which was initially created.

\section{"Travel Guide" - Edward Said, 1982}

Concepts are not set in stone. They travel, as Mieke Bal famously noted, "between disciplines, between individual scholars, between historical periods, and between geographically dispersed academic communities. Between disciplines, their meaning, reach, and operational value differ" (Bal 24). This differential aspect of travelling concepts is what is important, as it needs to be reassessed "before, during and after each trip" (Bal 24). In this trip we need to turn our attention to Edward Said and his seminal text from 1982, Travelling Theory.

As Said himself pointed out, the specific problem of what happens to a theory when it moves from one place to another is an important topic of research. He mapped out four stages which are common to the way any theory or idea travels:

1. The Point of Origin. "The set of circumstances in which the idea [...] entered discourse";

2. The Distance Transversed, which is described by Said as "a passage through the pressure of various contexts as the idea moves from an earlier point to another time and place where it will come into a new prominence";

3. Conditions of Acceptance, described as "an inevitable part of acceptance, resistances - which then confronts the transplanted theory or idea, making possible its introduction or toleration, however alien it might appear to be"; 
4. The New Position. "The now full (or partly) accommodated (or incorporated) idea is to some extent transformed by its new uses, its new position in a new time and place" (Said 226-227).

\section{Genealogy}

Following the four stages through which a theory travels I will attempt to map out what I will call the "genealogy" of theoretical models and their road from literary theory to film theory and adaptation studies. Before I begin tracing the way in which a theory is transformed, we should say that a concept, a theory or an idea is influenced in the same capacity by the road not taken as is influenced by the recognisable trajectory that can be recorded by the history of ideas. Following Nietzsche, Foucault speaks of genealogy not as something resembling a natural history, or the evolution of a species, but as a practice that tracks "the complex course of descent", which means "to maintain passing events in their proper dispersion", "to identify the accidents, the minute deviations or conversely, the complete reversals, the errors, the false appraisals, and the faulty calculations" (Foucault 81) of theoretical models. The "genealogy" that I am proposing following Foucault and Said is at once a critical practice and a type of analysis - the genealogical analysis of travelling theoretical models.

At this time, I have chosen to track the "genealogy" of very few theoretical sets of concepts, the reason for this choice being that they are clearly very well known by any scholar. First, I will track the way in which the formalist concepts of fabula and syuzhet have been imported from literary theory and transplanted into the filmic narratological theory of David Bordwell.

\section{From Russian Formalism to American Formalist Film Theory}

The genealogy that I am proposing is not a linear development. This is why I will not start with what Said calls the "point of origin" in which the theory entered discourse, but with the fourth stage, the new position in the theoretical model that the initial concepts were imported into. As all film scholars know, David Bordwell's work is a great example of formalist analysis and formalist method in the study of the poetics of cinema and film narratology. In his 
collective work with Kristin Thompson and his individual work, Bordwell has championed the influence of Russian Formalism on his film theory. The influence of formalist theory can be traced in three fields of interest: stylistic analysis and stylistic history of cinema, the poetics of cinema and the narratology of film. We will only focus on his work in narratology for now. In the "Introduction" to Narration in the Fiction Film, he poses the following theoretical question: How does narration operate in the fictional cinema? And then he states that, "given the book's topic, it is not implausible to draw upon the work of Russian Formalist critics“ like Viktor Sklovsky, Y. Tynyanov, Eichenbaum and that "concepts like syuzhet and fabula, motivation, retardation" (Bordwell xii) have all become indispensable to contemporary narrative theory. $\mathrm{He}$ also mentions the historical formalists interest in the poetics of cinema, by quoting the small anthology of formalist essays dedicated to film analysis published by Eichenbaum in 1927, Poetika Kino. Not surprisingly, Bordwell does not lose much sleep over the fact that the formalist concepts he is employing in the study of film narrative were the product of the formalist search for literariness. "Was not the search for 'literariness' an attempt to specify an intrinsically poetic function which is uncontaminated by extrapoetic demands?" (Bordwell xii). He answers that, while the Russian Formalists stressed the specificity of the aesthetic function, they also underlined the importance of social convention when it comes to defining what a work of art is. I argue that the problem Bordwell is facing is not a problem of choosing the appropriate method or theory for the development of narrative film theory, but a problem of aesthetics. And this problem can have a two-fold definition: the first one concerns medium specificity, the second one concerns the poetic use of the medium. At its core, the idea of medium specificity holds that every form of art has its own domain of expression and exploration. This domain is defined by the nature of the medium through which the objects of a given art form are composed. In many cases, the idea of the nature of the medium is thought of in terms of the physical structure of the medium, which defines the formal qualities of that particular medium. The medium specificity thesis can be summed up by saying that each art form should pursue those effects that - in virtue of its medium it alone - of all arts - can achieve. And this is how the idea 
of the poetic use of the material qualities of the medium is born. To give only an example, certain medium specificity theorists, like A. Bazin for instance, believe that cinema is essentially a realist medium and its ontology can be defined in terms of its photographic nature. The consequence of this belief is that only some qualities of the medium of film can be deemed cinematic. Bazin is referring to those material qualities that preserve spatial and temporal continuity, long shots and depth of field staging. It is unclear whether Bordwell believes that medium specificity should be defined in essentialist terms when it comes to cinema. But then he states that, for the Russian Formalists, "the difference between 'literary' and practical language varied historically and was thus purely relational and functional, not substantive and essentialist" (Bordwell xii). Even the term literariness contradicts Bordwell in this case. Bordwell does not take any time to ask himself whether the conditions in which formalist concepts were created were in fact essential to the use of those concepts. The reason for his assumption is that Bordwell relies on the readymade assumptions of Yury Tynyanov brought forth in his essay, The Fundamentals of Cinema. What Tynyanov calls the "film-novel" is actually what we call the fiction film today. He asks what is the difference between "the filmnovel" and the novel as a verbal genre. The difference, he states, "is not just in the material, but in the fact that style and structural laws transform in cinema all the elements which might have seemed to be distinct and equally applicable to all forms of art and to all its genres" (Tynyanov 11). Tynyanov believes that in resolving the problem of fabula and syuzhet we always have to take into account the specific material and style of an art form. In other words, unlike Bordwell, somebody like Tynyanov believed that in the importation of concepts from literary theory to film theory and film analysis, medium specificity and the material conditions of the medium have to be taken into account. No concept is perfectly tailored to every art form. When making an attempt to define fabula and syuzhet with regards to cinema, even Tynyanov admits that "since the problem of the fabula and syuzhet in film has been the least researched [...] I will permit myself to explain the relationship through literary material which is more thoroughly researched" (Tynyanov 11). So up to 1927, Tynyanov admits that there have been made no attempts to define the nature of syuzhet 
construction in cinema. That is why he turns to literature for examples. In his "Principles of Narration" chapter, Bordwell states that "We have seen theories of narration founded on superficial analogies between film and other media literature or theatre [...] The theory I propose sees narration as a formal activity [...] this theory treats narration as a process which is not in its basic aims specific to any medium". To be clear, Bordwell is not talking about what the structuralists called deep narrative structures. He states that "narration deploys the materials and procedures of each medium for its ends" (Bordwell 1985, 49). So different materials and procedures are deployed in literature and in film. In this case, I ask: what are the conditions of narrative that make fabula and syuzhet independent from the materials and procedures specific to each medium? Can concepts that were created in the analysis of literary language be employed in the analysis of film narrative? And to what extent? Are the devices of syuzhet construction in cinema similar to the devices of syuzhet construction in literature? The answer is of course, no. Bordwell's own analysis of the "Tactics of syuzhet construction" in film narrative is a good enough argument of this thesis. In fact, even Bordwell admits that the fabula/syuzhet conceptual pair survives only when it comes to dramaturgical relations in film narrative. When certain dramaturgical relations are emphasized, style becomes a key component of syuzhet construction. And style, as Bordwell himself has acknowledged, embodies a technical and material process (Bordwell 1985, 50). He does not go on to say whether he believes that medium specificity should be thought of in essentialist terms. Bordwell's importation of formalist concepts has not dealt with the issue of medium specificity of concepts created in the analysis of a certain type of language - i.e. literary language and literary discourse in this case.

Finally, to walk through the four stages described by Said, we can say that the point of origin of concepts like fabula and syuzhet is, as we all know, the work of Viktor Sklovsky from Theory of Prose. Regarding the distance transversed by these concepts, we must say that the first authors that imported the concepts from literary theory to film theory were the Russian formalists themselves, especially Tynyanov and Eichenbaum, but that even they were not sure if the concepts could be used in the analysis of film narrative. It is 
somewhat odd that Bordwell bypasses completely the transformations of these concepts in the structuralist analysis of narrative. In this regard, his importation makes a big detour. The conditions of acceptance in this case are dependent on bypassing the idea of medium specificity, an issue that to my knowledge, Bordwell has addressed only marginally. In Poetics of Cinema, he asks whether some poetic principles are specific to cinema. "Although certain poeticians have assumed a distinction between the cinematic and the noncinematic, this view isn't a postulate of poetics as such. You can assume that any film could be studied by poetics, with no film laying any closer to the essence of the medium than others. You could, though, also argue that the distinction between cinematic and noncinematic is not a substantive but rather a functional one, to be filled out in different periods with different content" (Bordwell 2012, 16). Finally, the New Position in which we find these concepts concerns the introduction of the idea that story construction depends heavily on what Bordwell deems the "viewer's activity", which mirrors reader-response theory in some respect. In fact, he even goes so far as to assert that the function of the narrator in film is taken up by the viewer of the film.

\section{Stage 5: Adaptation}

My objection to the way in which Bordwell borrows formalist concepts concerns the questions of aesthetics and poetics I have raised so far. But even with these objections, Bordwell's theory of narrative film still stands. Its strongest point is the stylistic and formal analysis Bordwell is known for. The only missing link from Bordwell's theory of narrative is what I would call a stage of adaptation. I am not referring to film adaptation, although mentioning it is not at all accidental. Instead I refer to the introduction of a fifth stage along the four other stages laid out by Said is speaking of. The adaptation of travelling concepts should be another individual stage, a different stage of the appropriation of concepts from external sources. In my example, the importation of formalist concepts should clarify to what extent these concepts were medium specific and to what extent the formalist quest for literariness was essential in the making of formalist narrative concepts. All these objections should be dealt with in the stage or the process of adaptation. 
Finally, when speaking of film adaptions of literary works, the issue of travelling concepts, which I will touch on briefly, is analysed more clearly by adaptation theory scholars. To take only the example of Robert Stam, who borrows concepts from Mikhail Bakhtin and Gérard Genette, adaptation is defined as "Intertextual dialogism". Being one of the major figures of the transtextual turn in film studies, Stam deals with the issue of medium specificity in the process of film adaption by speaking of the "grammar of transformation", a term which he uses to describe the process of film adaptation of a literary work and by using the concept of text also in the case of the film which is the result of adaptation. "One way to look at adaptation is to see it as a matter of the source novel hypotext's being transformed by a complex series of operations: selection, amplification, concretization, actualization, critique, extrapolation" (Stam 68), transcultural translation etc. "The source novel (...) can be seen as a situated utterance produced in one medium and in one historical context, then transformed into another equally situated utterance that is produced in a different context and in a different medium. The source text forms a dense informational network, a series of verbal cues that the adapting film text can then take up, amplify, ignore, subvert, or transform. The film adaptation of a novel performs these transformations according to the protocols of a distinct medium, absorbing and altering the genres and intertexts available through the grids of ambient discourses and ideologies, and as mediated by a series of filters: style, ideological fashion, political constraints, auteurist predilections” (Stam 68-69).

In conclusion, we can speak of adaptation in two instances. The first one deals with the film adaptation of literary works and is a trans-textual and transmedial practice. The second meaning of adaption, which I named, rather pretentiously, the genealogical analysis of travelling theoretical models, should be regarded as a work of aesthetics, poetics and art theory. It is this type of adaption that has led us to think of theories of narration in different types of media or what today we call transmedial narration or transmedia storytelling. Like literary themes, concepts are also used and reused, and the displacement of a concept from the theoretical framework it was originally created in can be a creative practice and can lead to the birth of new areas of study. 


\section{References:}

Bordwell, David. Narration in the fiction film, University of Wisconsin Press, 1985 .

---. Poetics of cinema, Routledge, 2012.

Deleuze, Gilles, Foucault, Michel, Intellectuals and power in Foucault, Michel, Language, Counter-memory, Practice. Selected Essays and Interviews, Cornell University Press, 1977, pp. 205-217.

Foucault, Michel, Nietzsche, Genealogy, History in The Michel Foucault Reader, Pantheon Books, 1984.

Said, Edward, Travelling Theory in The Text, the World and the Critic, Harvard University Press, 1983.

Stam, Robert, Beyond Fidelity: The Dialogics of Adaptation in Naremore, James (ed.), Film Adaptation, New Brunswick, Rutgers, 2000.

Tynyanov, Yury, The Fundamentals of Cinema in Eikhenbaum, Boris (ed.), Poetics of cinema, RPT Publications in association with Dept. of Literature, University of Essex, 1982, pp. 32-54. 